Jurnal Pendidikan Bahasa dan Sastra Indonesia is licensed under

A Creative Commons Attribution-Non Commercial 4.0 International License

\title{
Kebudayaan Lokal pada Cerita Pendek dan Cerita Rakyat Karya Mahasiswa IKIP PGRI Pontianak
}

\author{
Fitri Wulansari ${ }^{1)}$, Mesterianti Hartati ${ }^{2)}$ \\ 1) Program Studi Pendidikan Bahasa dan Sastra Indonesia, IKIP PGRI Pontianak \\ E-mail: fiwusa84@gmail.com \\ ${ }^{2)}$ Program Studi Pendidikan Bahasa dan Sastra Indonesia, IKIP PGRI Pontianak \\ E-mail: mesteriantihartati@yahoo.co.id
}

\begin{abstract}
Abstrak. Tujuan penelitian ini adalah mendeskripsikan dan menjelaskan kebudayaan lokal yang terkandung di dalam cerita pendek dan cerita rakyat karya mahasiswa IKIP PGRI Pontianak. Penelitian ini merupakan penelitian deskriptif kualitatif dengan metode analisis isi. Subjek penelitian yang digunakan adalah dokumen cerita pendek dan cerita rakyat karya mahasiwa IKIP PGRI Pontianak sebanyak lima cerita pendek dan lima cerita rakyat. Hasil penelitian menunjukkan bahwa terdapat tiga jenis kebudayaan lokal di dalam cerita pendek dan cerita rakyat karya mahasiswa IKIP PGRI Pontianak. Ketiga jenis itu adalah kerajinan tangan, permainan rakyat, dan acara adat.
\end{abstract}

Kata Kunci: cerita pendek; cerita rakyat; kebudayaan lokal

\section{PENDAHULUAN}

Karya sastra merupakan sebuah karya seni yang berasal dari pikiran yang mampu memberikan nilai-nilai kehidupan dan hiburan kepada penikmanya. Kehadiran sebuah karya sastra berasal dari pemikiran pengarang terhadap aspekaspek hebidupan masyarakat. Menurut Winarsih (2009:7) menjelaskan bahwa sastra adalah hasil kreativitas pengarang yang bersumber dari kehidupan manusia secara langsung atau melalui rekaannya dengan bahasa sebagai mediannya. Dengan pernyataan tersebut dapat dijelaskan bahwa karya sastra mencerminkan kehidupan masyarakat sehari-hari. Oleh sebab itu, satu di antara karya sastra yang sangat diminiati masyarakat adalah cerpen dan cerita rakyat.

Cerpen atau cerita pendek adalah sebuah karya sastra yang sangat simple, karena cerpen tidak memiliki banyak tokoh dan insiden-insiden. Akan tetapi cerpen memiliki kesan yang sangat menarik. Menurut Purba (2010:51) menyatakan cerita pendek adalah kisah pendek kurang dari 10.000 kata yang dimaksudkan member kesan tunggal yang dominan. Jadi dapat dijelaskan pendapat tersebut mengenai cerpen adalah cerita yang dapat dibacakan dalam hitungan jam saja serta memiliki jumlah kata biasanya di bawah 10.000 kata.

Cerita rakyat merupakan suatu ungkapan yang imajinatif dari pengarang yang dimiliki masyarakat kolektif. Cerita rakyat sesungguhnya menyimpan berbagai kearifan lokal yang dapat dijadikan sebagai sarana pendidikan serta menyimpan asset budaya masyarakat. Menurut Semi (2013:79) cerita rakyat adalah suatu cerita yang pada dasarnya disampaikan secara lisan. Jadi sudah cukup jelas cerita rakyat merupakan suatu upaya anggota masyarakat untuk memberi dan mendapatkan hiburan yang berkembang secara turun temurun dan tersebar secara lisan.

Kebudayaan lokal merupakan latar belakang dari kebiasaan-kebiasaan kelompok masyarakat tertentu. Kearifan lokal maupun pengetahuan lokal juga merupakan bagian kebudayaan lokal. Menurut Sularso dan Maria (2017: 3) menyatakan bahwa kebudaan lokal bisa berwujud atau berbentuk nilai-nilai yang tidak nampak namun diyakini dan dilaksanakan oleh suatu kelompok tertentu. Dari pernyataan tersebut dapat diartikan bahwa kebudayaan lokal tersebut mengandung nilai-nilai yang berhubungan dengan kehidupan yang diwarisi secara turun temurun sebagian kelompok masyarakat. Nilai-nilai yang diyakini kebenarannya dan menjadi acuan dalam bertingkah laku sehari-hari masyarakat tersebut.

Adapun tujuan dalam penelitian ini adalah mendeskripsikan dan menjelaskan mengenai kebudayaan lokal yang terkandung di dalam cerita pendek dan cerita rakyat karya mahasiswa IKIP PGRI Pontianak. Pemilihan kebudayaan lokal yang akan diteliti karena mengingat isu yang ada di Negara kita mengenai kebudayan yang sering diakui hak miliknya dari negara lain. Semua hal itu berasal 
dari globalisasi sehingga generasi muda lebih mengenal kebudayaan asing dibandingkan kebudayaan lokal.

\section{METODE}

Penelitian ini merupakan penelitian dokumen berupa cerpen dan cerita rakyat karya mahasiswa IKIP PGRI Pontianak. Penelitian ini juga menggunakan bentuk penelitian deskriptif kualitatif dengan metode analisis isi. Penelitian ini mendeskripsikan mengenai budaya lokal yang terkandung di dalam cerpen dan cerita rakyat karya mahasiswa IKIP PGRI Pontianak.

Pengumpulan data penelitian dilakukan dengan menggunakan analisis isi cerpen dan cerita rakyat. Data dalam penelitian ini adalah kajian mengenai isi cerpen dan cerita rakyat karya mahasiswa IKIP PGRI Pontianak yang berhubungan dengan kebudayaan lokal. Sumber data penelitian ini adalah lima cerpen dan lima cerita rakyat karya mahasiswa IKIP PGRI Pontianak berdasarkan fenomena kebudayaan lokal.

Teknik analisis data yang digunakan adalah model analisis interaktif yang digunakan Miles dan Huberman (Sutopo, 2006:107) mencakup: (1) pengumpulan data; (2) reduksi data; (3) penyajian data; dan (4) penarikan kesimpulan.

\section{HASIL DAN PEMBAHASAN}

Ada tiga jenis kebudayaan lokal yang terkandung di dalam cerpen dan cerita rakyat karya mahasiswa IKIP PGRI Pontianak, yaitu (1) kerajinan tangan; (2) permainan rakyat; dan (3) acara adat. Klasifikasi jenis kebudayaan lokal dalam cerpen dan cerita rakyat karya mahasiswa IKIP PGRI Pontianak tampak dalam uraian selanjutnya.

\section{Kerajinan Tangan}

\section{"Bagaimana kalau kita mencari tahu lebih dalam tentang kain tenun Sambas?”}

Pada data cerpen karya Indah Sari dengan judul cerpen Pertualangan Mencari Tahu Tentang Tenun di atas terdapat kebudayaan lokal. Kebudayaan lokalnya adalah kerajinan tangan yang berupa kain tenun. Kain tenun Sambas yang mana kain tenun ini selalu digunakan oleh warga masyarakat Sambas pada saat upacara adat perkawinan yang mana kain tenun ini juga memiliki berbagai macam motif, motif yang paling terkenal, yaitu adalah motif pucuk rebung yang mana warga masyarakat Sambas percaya motif pucuk rebung ini memiliki makna yang luas dan mendalam.

\section{"ia kemudian minta dibuatkan otot baukir"}

Pada data cerita rakyat karya Triponia Anjelina dengan judul Legenda Bujang Nyangko di atas terdapat kebudayaan lokal. Kebudayaan lokalnya adalah kerajinan tangan yang berupa otot baukir atau lebih sering didengar dengan kata tato. Otot baukir ini adalah satu di antara kerajinan tangan suku Dayak. Otot baukir digunakan suku Dayak setiap ada acara adat-adat mereka. Otot baukir digambarkan di setiap kaki dan tangan mereka sewaktu melakukan acara adat.

\section{Permainan Rakyat}

\author{
"Meriam itu semacam bom untuk nguser antu \\ kuntilanak hahaha... “
}

Dari data di atas terdapat kebudayaan lokal yang terkandung di dalam cerpen Dentuman Meriam Mempererat Persahabatan Karya Kartia Hariati ini terdapat kerajinan tangan yang menggambarkan kebudayaan lokal Kalimantan Barat khususnya Kota Pontianak. Hal ini dapat terlihat di dialog yang menceritakan permainan meriam. Permainan meriam di bulan Ramadhan sangat khas dengan kebudayaan Kota Pontianak. Karena permainan ini di lakukan setiap tahun di Bulan Ramadhan yang menggambarkan sejarah Kota Pontianak. Pada sejarahnya, permainan meriam ini dilakukan untuk mengusir hantu-hantu kuntilanak yang mengganggu warga. Tapi permainan meriam saat ini bukan digunakan untuk mengusir warga, akan tetapi mengenang sejarah terjadinya Kota Pontianak saja.

"Adik terlihat begitu bahagia karena dia bisa mengalahkan paman serta teman-temannya bermain gasing"

Dari data di atas terdapat kebudayaan lokal yang terkandung di dalam cerpen Kupijak Bumi Dara Nante Karya Natalia Susi. Data di atas menceritakan permainan Gasing. Gasing adalah mainan bisa berputar pada poros dan berkeseimbangan pada suatu titik. Sebagian besar gasing dibuat dari kayu. Kayu diukir dan dibentuk hingga menjadi bagian badan gasing. Tali gasing dibuat dari kulit pohon. Permainan gasing ini dilakukan sebelum musim panen padi hingga musim panen berlangsung.

"Sebelum saatnya pihak keluarga calon pengantin lakilaki melemparkan pantun yang lalu pantun itu mesti di jawab oleh pihak keluarga pengantin wanita”.

Pada data cerita rakyat karya Nuriyati dengan judul Antar Uang di atas terdapat kebudayaan lokal. Kebudayaan lokalnya adalah permainan berbalas pantun. Permainan berbalas pantun adalah permainan antara dua kelompok saling melemparkan pantun dan wajib dibalas oleh kelompok lainnya. Permainan berbalas pantun ini dilakukan sebelum ritual Antar Uang. Ritual Antar Uang atau lamaran ini dilakukan oleh masyarakat Sambas. Ritual ini dilakukan secara turun temurun.

\section{Acara Adat}

"Aku baru sadar, hari ini Ibu akan sibuk memasak makanan karena besok adalah upacara kelahiran orang Bugis, yaitu naik ayon”. 
Dari data di atas terdapat kebudayaan lokal yang terkandung di dalam cerpen Naik Ayun Jantung Kehidupan Karya Nisa Aqila ini menceritakan acara adat suku Bugis, yaitu naik ayon. Naik ayon adalah acara untuk anak yang baru lahir sebelum umur 40 hari. acara ini digunakan untuk menghindari hal-hal buruk yang terjadi kepada anak-anak yang baru lahir. Acara naik ayon ini sudah sedikit masyarakat suku Bugis yang ada di Kalimantan Barat melakukannya karena terkikis oleh globalisasi.

"Satu Minggu kemudian tiba waktu untuk acara gawai Dayak tiba, aku bersiap untuk pergi"

Dari data di atas terdapat kebudayaan lokal, yaitu acara gawai Dayak yang terkandung di dalam cerpen yang berjudul Ku Pijak Bumi Dara Nante Karya Natalia Susi ini merupakan satu di antara kebudayaan lokal masyarakat suku Dayak. Acara ini diadakan setiap satu tahun sekali dan acara gawai ini dilakukan setelah panen padi berlangsung. Diadakannya gawai Dayak ini merupakan suatu wujud syukur kepada Tuhan karena hasil panennya sesuai dengan keinginan masyarakat tersebut.

"Ketika mulai gelap upacara manang pun di mulai, Piang Buluh menguarkan batu-batu pustaka miliknya beserta dengan botol-botol kecil yang berisi minyak"

Dari data di atas terdapat kebudayaan lokal, yaitu acara gawai Dayak yang terkandung di dalam cerita rakyat yang berjudul Bermanang Karya Natalia Susi ini merupakan satu di antara kebudayaan lokal masyarakat suku Dayak Kantuk. Adat kebudayaan ini dilakukan dengan cara bermanang namun bermanang ini memiliki syarat yang mana masyarakat suku Dayak Kantuk ini percaya bahwa orang yang melihat tidak boleh bertanya akan tetapi hanya boleh menatapi mata dengan mata dan diam saja jika syarat ini dilanggar maka akan terjadi suatu musibah yang akan menimpa orang tersebut.

\section{IV.SIMPULAN}

Berdasarkan analisis terhadap data yang berkaitan dengan kebudayaan lokal yang terkandung di dalam cerpen dan cerita rakyat karya mahasiswa IKIP PGRI Pontianak, yaitu kebudayaan lokal mengenai kerajinan tangan, kebudayaan lokal mengenai permainan rakyat, dan kebudayaan lokal mengenai acara adat. Selain ketiga jenis kebudayaan lokal yang dianalisis ini, kebudayaan lokal lain masih banyak akan tetapi tidak ditemukan di dalam cerpen dan cerita rakyat karya mahasiswa IKIP PGRI Pontianak.

\section{UCAPAN TERIMA KASIH}

Terima kasih peneliti ucapkan kepada semua pihak yang telah ikut membantu dalam penelitian ini. Penelitian yang berjudul Kebudayaan Lokal dalam Cerpen dan Cerita Rakyat Karya Mahasiswa IKIP PGRI Pontianak. Terkhusus ucapan terima kasih ini untuk DRPM Ditjen Penguatan Risbang yang telah membantu dalam pendanaan penelitian ini. Selain itu, ucapan terima kasih ini juga diucapkan kepada lembaga IKIP PGRI Pontianak yang telah menfasilitasi sehingga penelitian ini dapat terlaksanakan.

\section{DAFTAR PUSTAKA}

Purba, Antilan. (2010). Sastra Indonesia Kontemporer. Yogyakarta: Graha Ilmu.

Pryo Sularso dan Yuli Maria. (2017). "Upaya Pelestarian Kebudayaan Lokal melalui Ekstrakurikuler Karawitan di SMP Negeri 1 Jiwan Tahun 2016". Jurnal Pendidikan Pancasila dan Kewarganegaraan, 6(2): $1-12$.

Semi, Atar. (2013). Kritik Sastra. Bandung: Angkasa.

Sutopo, H. B. (2006). Metodelogi Penelitian Kualitatif: Dasar, Teori, dan Terapannya dalam Penelitian. Surakarta: UNS Press.

Winarni, Retno. (2009). Kajian Sastra. Salatiga: Widya Sari Press. 